\title{
ЗАБЕЗПЕЧЕННЯ ЯКОСТІ ВИЩОЇ ОСВІТИ В ЄВРОПЕЙСЬКОМУ ПРОСТОРІ ОЧИМА СТУДЕНТІВ
}

\begin{abstract}
У статті вказано, щчо основною метою створення Свропейського простору вищої освіти стало підвищення якості вищчої освіти та визначено, щзо представником студентства в процесі забезпечення якості вищої освіти виступає Європейський студентський союз. У статті детально схарактеризовано утворення Союзу та зосереджено увагу на основних рекомендаціях щзоо процесу забезпечення якості вищої освіти в регулярних звітах «Болонський прочес очима студентів». У 2003 рочі було виокремлено такі першочергові аспекти розвитку, як можливості студентства щзодо здобуття якісної освіти, перешкоди розвитку мобільності, залучення студентів до прочесу забезпечення якості. У матеріалах публікації 2005 року висвітлено рівень упровадження реформ на національному та інституційному рівнях. 3 метою підвищення надійності та функціонування процедур забезпечення якості національні системи забезпечення якості мають включати визначення обов'язків залучених закладів вищої освіти, оцінку програм, систему акредитаџї, сертифікації або порівняння процедур, співпрацю та створення мереж. У матеріалах публікацї 2007 року було визначено проблемні тенденцї розвитку процесу забезпечення якості вищої освіти, серед яких неодночасність приєднання до Болонського прочесу, власні пріоритети кожної краӥни, відсутність систем із забезпечення якості в деяких краӥнах. У 2009 рочі було визнано, щзо реалізація рекомендацій дозволить упровадити створення Свропейського простору вищої освіти та привести Болонський процес до успішного завершення протягом наступного десятиліття. Матеріали публікаиії за 2012 рік містили важливі рекомендащії щуодо подальшого розвитку Болонського процесу. У 2015 році було зазначено, щчо забезпечення якості має залишатися пріоритетом для систем вищої освіти. У звіті 2018 року основними напрямами стали: культура якості, побудова довіри, змішані підходи до зовнішнього забезпечення якості, реалізачія участі студентів у прочесі забезпеченні якості, забезпечення прозорості та інформації, Європейський реєстр забезпечення якості як інструмент прозорості.

Ключові слова: Свропейський простір вищьӧ освіти, якість вищої освіти, Свропейські стандарти та рекомендації щзодо забезпечення якості вищої освіти, Свропейська кредитно-трансферна система, Болонський процес, зовнішнє забезпечення якості, внутрішнє забезпечення якості, Свропейський реєстр забезпечення якості вищої освіти.
\end{abstract}

Vasyl BILOKOPYTOV, orcid.org/0000-0002-4412-1993

Candidate of Pedagogical Sciences, Associate Professor at the Foreign Language Department Sumy National Agrarian University (Sumy,Ukraine)belvas67@ukr.net

\section{QUALITY ASSURANCE ON EUROPEAN AREA OF HIGHER EDUCATION WITH STUDENT EYES}

In the article it is indicated that the main purpose of the European Higher Education Area was to improve the quality of higher education and that the student body is represented by European Students' Union in the process of higher education quality assurance. It is designated the formation of the Union and the main recommendations for the process of higher education quality assurance in the regular reports "Bologna With Student Eyes". In 2003, such priority aspects as the opportunities of students to obtain quality education, obstacles to the development of mobility, the involvement of students in the quality assurance process were emphasized. The 2005 publication gave accent to the level of reform implementation at the national and institutional levels. In order to improve the reliability and functioning of quality assurance procedures national quality assurance systems should include defining the responsibilities of the involved higher education institutions, evaluating programs, a system of accreditation, certification or comparison of procedures, cooperation and networking. The 2007 publication identified problematic trends in the development of the quality assurance process in higher education, including the non-simultaneity of joining the Bologna Process, each country's own priorities, and the lack of quality assurance systems in some countries. In 2009, it was recognized that the 
implementation of the recommendations would lead to the creation of the European Higher Education Area and bring the Bologna Process to a successful accomplishment over the next decade. The publication for 2012 contained important recommendations for the further development of the Bologna Process. In 2015, it was identified that quality assurance should continue to be a priority for higher education systems. In the 2018 report, the main areas were: quality culture, confidence, mixed approaches to external quality assurance, implementation of students 'participation in the process of quality assurance, transparency, information and European Quality Assurance Register as a tool of transparency.

Key words: European Higher Education Area, quality of higher education, European Standards and Guidelines for Quality Assurance, European Credit Transfer System, Bologna process, external quality assurance, internal quality assurance, European Quality Assurance Register for Higher Education.

Постановка проблеми. Підвищення якості вищої освіти стало основною метою утворення Європейського простору вищої освіти (далі СПВО). Як провайдери освітніх послуг, так і їхні споживачі, якими є студенти, відіграють вагому роль у процесі підвищення та забезпечення якості. Представником студентства на ЄПВО в сучасних умовах виступає Європейський студентський союз. Шлях Союзу до участі в Болонському процесі (далі - БП) був складним, оскільки на початкових його етапах участь студентства не передбачалася.

Аналіз досліджень. Під час висвітлення проблеми дослідження було детально проаналізовано документи щодо історії створення Європейського студентського союзу. Особливу увагу було приділено вивченню регулярних публікаційзвітів «Болонський процес очима студентів» за 2003-2018 роки.

Мета статті - висвітлення та характеристика діяльності Європейського студентського союзу через аналіз публікацій «Болонський процес очима студентів» (Bologna WithStudents Eyes) для кращого розуміння як потреб студентства в якісній освіті, так і їхньої ролі в процесі забезпечення якості.

Виклад основного матеріалу. У жовтні 1982 у Стокгольмі зібралось сім національних студентських союзів (Норвегія, Об'єднайте Королівство Великої Британії та Північної Ірландії, Швеція, Ісландія, Франція, Данія, Австрія), щоб утворити Західноєвропейське студентське інформаційне бюро (ЗССІБ) - West European Student Information Bureau (WESIB). Метою Бюро було координувати потік інформації між учасниками проекту та 3 європейських і міжнародних організацій (Рада Європи, Свропейська спільнота та ЮНЕСКО).

Політичні зміни в Східній Свропі наприкінці 1980-х років вплинули і на Бюро, оскільки воно було відкрито для національних студентських союзів із бувшого Сходу. У лютому 1990 р. в назві зникає слово «західно», і утворюються нова назва Свропейське студентське інформаційне бюро (ССIБ) - European Student Information Bureau (ESIB).

Через те, що Європейська спільнота почала досягати більшого впливу на європейській сцені вищої освіти за допомогою програм Socrates and
Erasmus, національні студентські союзи в Європі вирішили змінити цілі Бюро 3 простого поділення інформацією до політичної організації, яка представляла інтереси студентства європейським інституціями.

У травні 2007 року було вирішено, що ЄСІБ потребує зміни назви для того, щоб краще відобразити діяльність організації. Виконавчий комітет запропонував назву Свропейський студентський союз (далі - ЄСC) - European Students' Union (ESU). Абревіатура та назва були одноголосно прийняті.

Основна мета ССС - представляти та заохочувати освітні, соціальні, економічні та культурні інтереси студентів на європейському рівні по відношенню до всіх важливих учасників (Європейський союз, група супроводу Болонського процесу, Рада Європи та ЮНЕСКО). Позиція ЄСС щодо забезпечення якості освіти (ЗЯВО) висвітлюється в серії аналітичних розвідок експертів організації під спільною назвою «Болонський процес очима студентів» (Bologna With Students Eyes), що були опубліковані у 2003, 2005, 2007, 2009, 2012, 2015, 2018 роках.

В аналітичній роботі 2003 року виокремлено такі першочергові аспекти розвитку СПВО: переваги БП; можливості студентства щодо здобуття якісної освіти, які надає створення СПВО; загрози впровадженню БП; плата за навчання; перешкоди розвитку мобільності; залучення студентів до процесу забезпечення якості; впровадження структури академічних ступенів бакалавр /магістр; Свропейська кредитно-трансферна система. (Almqvist, 2003: 1).

У матеріалах публікації 2005 року висвітлено рівень упровадження реформ на національному та інституційному рівнях.

Багато країн та інших стейкхолдерів розглядали питання забезпечення якості як один із наріжних каменів Болонського процесу. Для Свропи ніколи не намагалися розробити єдину систему забезпечення якості, а скоріше, посилити співпрацю в забезпеченні якості. Питання взаємної довіри в системах забезпечення якості відіграло вирішальну роль у цьому відношенні. 3 метою 
підвищення надійності та функціонування процедур забезпечення якості міністри, відповідальні за вищу освіту, домовилися на зустрічі в Берліні у 2003 році, що до 2005 року національні системи забезпечення якості мають включати: а) визначення обов'язків залучених закладів вищої освіти; б) оцінку програм або закладів вищої освіти, включаючи внутрішню оцінку, зовнішній огляд, участь студентів та публікацію результатів; в) систему акредитації, сертифікації або порівняння процедур; г) міжнародну участь, співпрацю та створення мереж (Bauman, 2005: 23).

Крім цього, вважаємо за необхідне виокремити такі фактори, які вплинули на рівень впровадження БП: 1) різні «стартові» позиції країн (на момент впровадження БП у деяких країнах уже існували двоступеневі системи й (КТС); 2) країни неодночасно приєдналися до БП; 3) кожна країна мала свої власні пріоритети, що призвело до недосконалого впровадження одних дій і нехтування іншими; 4) на ринку праці мали місце проблеми 3 працевлаштуванням фахівців зі ступенями бакалавр/магістр; 5) у деяких країнах усе ще не було систем із забезпечення якості (Bauman, 2005: 23).

Проблемні тенденції розвитку процесу забезпечення якості вищої освіти (ЗЯВО) було визначено в матеріалах публікації «Болонський процес очима студентів» 2007 року. Для подальшого розвитку процесу 3ЯВО, на думку експертів, слід було б урахувати такі рекомендації: 1) збільшити залучення студентів до процесу ЗЯВО, зокрема, необхідно залучення всіх рівнів забезпечення якості та чітке визначення ролі студентів як повноправних партнерів процесу; 2) потреба в подальшому обговоренні того, як зовнішнє забезпечення якості може ефективно та надійно забезпечити якість кожної навчальної програми і водночас може бути ефективним у запобіганні непотрібної бюрократії; 3) активізувати впровадження Свропейських стандартів та рекомендацій щодо забезпечення якості (далі - ССР) на національному рівні та вжити заходів для підвищення обізнаності європейських студентських союзів щодо $\mathrm{CCP}$; 4) посилити роботу щодо прозорості й довіри до забезпечення якості через Європейський реєстр забезпечення якості вищої освіти. На етапі впровадження необхідна доступна інформація про Європейський реєстр, щоб покращити знання та підвищити рівень обізнаності про неї (Mikkola, 2007: 15-16).

Надзвичайно важливим для дослідження був аналіз змін у процесі ЗЯВО. За період 2005-2007 pp. ЗЯВО досягло певної ваги і на національному, і на європейському рівнях. Хоча питання забезпечення якості існувало в деклараціях та комюніке БП з 1999 року, насправді це питання перетворилося на центральне після Берлінського комюніке (залучення студентів до процесу забезпечення якості).

Основними рекомендаціями на наступні роки в підсумковому звіті 2009 року стали:

- зобов'язання, узгоджені $з$ діями - міністри повинні переглянути всі зобов'язання та всі узгоджені напрями дій, взяті в міністерських комюніке. Крім цього, всебічно оцінити, які з них були повністю досягнуті, а які ще потребують подальших упроваджень. А головне те, що заклад вищої освіти (ЗВО) та студенти повинні бути залучені до цієї оцінки;

- від планів на папері до практичних дій - міністри повинні висловити чітке зобов'язання щодо реалізації всіх напрямів БП в однаковій мірі. Міністерства освіти кожної країни-підписанта Болонської угоди мали співпрацювати з ЗВО та студентами для створення справжнього партнерства, яке перетворить слова на конкретні реалії і поставить кінець все ще існуючому селективному підходу;

- підвищення рівня мобільності - для координації зусилля слід розробити та запровадити цільовий і чіткий план дій для забезпечення більшої збалансованої мобільності в рамках СПВО, а також створити необхідний імпульс для реального прогресу поставленої мети;

- національні плани дій щодо соціального виміру - слід докласти зусиль для того, щоб національні плани дій були розроблені для всіх країн-підписантів Болонської угоди, i, крім того, їх розроблення та впровадження здійснювалась за повної участі студентів;

- посилення участі студентів - там, де ще не існує участь студентів, необхідне законодавство для забезпечення мінімального рівня залучення студентів до інституційного рівня забезпечення якості, а там, де існує таке законодавство, воно повинно бути повністю впровадженим, щоб студенти брали участь у процесі прийняття рішення. Студенти повинні розглядатися як рівноправні партнери в управлінні процесом забезпечення якості на інституційному рівні;

- дії щодо національних рамок кваліфікацій набагато більше зусиль необхідно направити на розроблення національної рамки кваліфікацій для кожної країни з повним залученням студентів та інших стейкхолдерів;

- оцінка та поширення ССР - процес оцінювання ССР повинен ініціюватися консультативним шляхом, щоб переглянути вже існуючий успіх з їх виконанням; 
- збільшення внеску студентів до процесу забезпечення якості - терміново необхідна подальша робота для забезпечення того, щоб студенти розглядалися рівноправними партнерами як у внутрішньому, так і в зовнішньому забезпеченні якості;

- студентоцентроване навчання - збільшення участі студентів у побудові систем навчання, які спираються на послідовне одночасне впровадження всіх структурних інструментів БП;

- підвищення можливостей працевлаштування - впровадження повноцінної системи 3 трьох циклів має бути пріоритетним і здійснюватися таким чином, щоб виконувати ії первісну мету - створити гнучкість у шляхах навчання та надати більше можливостей для працевлаштування. Процес повного впровадження має супроводжуватися консультаціями і спілкуванням як із роботодавцями, так і з суспільством в цілому;

- впровадження навчання впродовж життя як складової частини системи освіти - має розглядатися як невід'ємна частина зусиль для створення нових, більш відкритих та відповідальних установ. Забезпечення якості та громадська відповідальність повинні бути в центрі національних стратегій навчання впродовж життя, причому участь стейкхолдерів забезпечуватиме власність академічної спільноти над цим основним пріоритетом на наступне десятиріччя;

- розвиток докторської освіти шляхом забезпечення рівної підтримки всіх докторантів - докторанти мають отримувати рівну підтримку, незалежно від їхнього статусу (працівники, студенти, молоді дослідники тощо). Крім того, участь докторантів у розвитку зв'язку між освітою та дослідженням мають важливе значення, і національні студентські спілки повинні бути залучені до процесів прийняття рішень, пов'язаних із третім циклом та дослідженнями в цілому;

- розвиток відносин 3 рештою світу на основі співпраці та сталого розвитку - посилення відносин повинно здійснюватися із взаємною повагою та визнанням різних контекстів і необхідності вчитися у колег, забезпечуючи при цьому повну участь зацікавлених сторін. Міжнародна мобільність також має бути посилена зобов'язанням захищати права іноземних студентів, забезпечувати доступ до інформації, забезпечувати високу якість освіти та відмову від прийняття політики, що сприяє витіканню молоді з країни.

Отже, ССС твердо вірить, що реалізація цих рекомендацій дозволить реалізувати створення СПВО, як це і було передбачено, та привести БП до успішного завершення протягом наступного десятиліття (Cacciagrano, 2009: 11-14).
Найважливішим документом за весь період діяльності на той час стала аналітична публікація «Болонський процес на фінішній лінії: звіт за десять років реформ європейської вищої освіти» ("Bologna at the Finish line: An account of ten years of European higher education reform"), яка підтвердила позицію $\mathrm{CCC}$ щодо пошуків нових шляхів ЗЯВО. Щодо студентської мобільності, то ЄСС виступив 3 такими рекомендаціями: а) мобільність повинна бути підтримана в усіх іiі видах i на всіх іiі рівнях; б) існування належного фінансування для потреб повномасштабної мобільності на СПВО; в) у глобальному контексті мобільність уважається потенційним ринком, а отже, і додатковим джерелом фінансування для ЗВО (Bartollo, 2010: 16-17).

Матеріали публікації за 2012 рік, крім аналізу змін в основних положеннях БП за попередні три роки, містили, на нашу думку, важливі рекомендації щодо подальшого розвитку БП, а саме:

- неможливість досягнення цілей БП без необхідної фінансової підтримки соціального виміру, студентської мобільності та навчання впродовж життя;

- прискорення студентської мобільності та іiі доступність, незалежно від соціально-економічного походження;

- розроблення процедур для балансування мобільності та подолання інформаційних перешкод;

- посилення актуальності та розширення доступу до вищої освіти з метою подолання соціально-економічної кризи;

- встановлення більш потужного механізму моніторингу та порівняння щодо підтримки соціального виміру у вищій освіті;

- необхідність у тому, щоб стажування та практична освіта стали частиною навчальної програми;

- заохочення розвитку навчання, спрямованого на студента;

- гарантування гнучкої та відкритої прогресії між циклами навчання та СКТС для вирівнювання результатів навчання в більшості країн СПВО;

-перегляд ССР закцентомнаїхнімету, масштаби, ясність та зручність використання (Рӓll, 2012: 8-9).

У звіті «Болонський процес очима студентів» за 2015 рік зазначено, що забезпечення якості має продовжувати залишатися пріоритетом для систем вищої освіти, щоб усунути перешкоди для прийняття, продовження та успішного завершення ступенів. Вона повинна забезпечити академічну свободу, інтеграцію викладання, навчання та досліджень, а також підготувати студентів до того, щоб вони були активними громадянами 
в майбутньому, не виключаючи жодної групи в суспільстві. Такі рекомендації повинні бути реалізовані в майбутньому до наступної конференції міністрів у 2018 році:

- системи забезпечення якості повинні грунтуватися на принципах та цінностях довіри, участі й власності зацікавлених сторін та прагнення до реального вдосконалення;

- внутрішнє забезпечення має охоплювати оцінювання та моніторинг усіх освітніх заходів у межах ЗВО. Звіти з оцінки повинні бути доступними для студентів, інших зацікавлених сторін і широкої громадськості. Вони мають включати рекомендації щодо подальшого вдосконалення;

- необхідно створити такі незалежні агенції в кожній країні для проведення додаткових оглядів та забезпечення підтримки в підвищенні якості на інституційному та програмному рівні;

- студенти повинні вважатися рівними членами системи вищої освіти та/або представляти студентів у процесах прийняття рішень внутрішнього і зовнішнього забезпечення якості. Значуще представництво студентів $є$ обов'язковою умовою в забезпеченні якості;

- важливо, щоб переглянута версія ЄСР на ЄПВО (2015 р.) швидко впроваджувалася у співпраці $з$ національними стейкхолдерами. Стандарт навчання, орієнтований на студента, має бути надзвичайно важливим, і країни по всьому світу повинні прагнути до повної трансформації національних положень для виконання цього стандарту на практиці під час проведення оглядів 3 повним і значним залученням студентів;

- необхідно вивчити можливості для подальшого розвитку цього реєстру, щоб надати інформацію про якість забезпечення вищої освіти на ЄПВО. Наприклад, цього можна досягнути шляхом створення бази даних ступенів та навчальних програм, що пропонуються в межах ЄПВО (O’Driscoll, 2015: 37).

Переходимо до рекомендацій щодо ЗЯВО у звіті 2018 року:

- культура якості - забезпечення якості повинно розглядатися як інструмент культури якості, а не набір формальних процедур. Для досягнення більш високої культури якості основна увага має бути надана реалізації процесу забезпечення якості на інституційному рівні. Індивідуальний підхід до впровадження має бути дотриманим i застосованим у кожному закладі, оскільки в забезпеченні якості не існує єдиного рішення;

- побудова довіри - існує підвищене усвідомлення важливості створення довіри як важливої мети забезпечення якості серед студентів. Ця мета повинна широко пропагуватися, оскільки вона служить для того, щоб забезпечення якості базувалось на надійних, прозорих та відповідних джерелах інформації та пояснювальних процедурах у прийнятті рішень;

- змішані підходи до зовнішнього забезпечення якості - інституційні та програмні підходи до зовнішнього забезпечення якості мають доповнювати один одного, оскільки вони розглядають різні сторони освіти та ЗВО;

- реалізація участі студентів у забезпеченні якості - умови для участі студентів повинні надавати широку та змістовну участь на міжнародному та зовнішньому рівнях. Рівне та необмежене членство студентів у будь-якому органі, що приймає рішення, має бути ключовою частиною будьякого процесу забезпечення якості. Студентів слід розглядати як найважливішу частину циклів зворотного зв'язку в межах внутрішнього забезпечення якості, зокрема, в розгляді питань удосконалення навчальних програм;

- студенти в центрі політичної реформи місце студентів у розробленні освітньої політики на національному рівні повинно бути посилено та підтримано. Зараз це залишається недостатнім, i будь-які реформи національної політики щодо забезпечення якості мають бути спрямовані на потреби студентів;

- участь студентів як фундаментальна цінність ЄПВО - значна участь студентів повинна залишатися в центрі уваги БП як однієї з основних цінностей ЄПВО, і має бути приділено більше уваги в подальшій роботі групи супроводу БП;

- забезпечення прозорості та інформації - для того щоб подолати брак інформації щодо забезпечення якості, необхідно організувати відповідну підготовку для студентів, викладачів та адміністративного персоналу;

- вплив на забезпечення якості - процес забезпечення якості повинен супроводжуватися відповідними діями, а наслідки повинні постійно демонструватися для висвітлення поліпшень, які $\epsilon$ результатом участі всіх зацікавлених сторін;

- справжня реалізація ЄСР - реалізація ССР має дотримуватися як на рівні політики та практики, так і на національному та інституційному рівнях. Слід запобігти тому, щоб ССР залишилися простими цілями політики та вирішували б нестачу волі/ресурсів для реальної реалізації;

- Свропейський реєстр забезпечення якості як інструмент прозорості - реєстр повинен продовжувати свою роботу з підвищення прозорості, але його роль також має бути передана в зрозумілому вигляді і через більш широкі канали для націо- 
нальних стейкхолдерів. Як інструмент реєстр має сприяти досягненню позитивного впливу на підвищення прозорості та довіри (Sundberg, 2018: 52-53).

Висновки. Таким чином, вивчення та детальний аналіз діяльності Європейського студентського союзу від самого його утворення дозво- ляє дійти висновку: хоча шлях Союзу до участі в Болонському процесі й був складним, але в досягненні основної мети ЄСС став потужним рівноправним партнером у групі супроводу БП i впевнено зайняв вагоме місце серед основних учасників БП.

\section{СПИСОК ВИКОРИСТАНИХ ДЖЕРЕЛ}

1. Almqvist J., Baumann B., Fontes P. Introduction to ESIB. Bologna With Student Eyes. 2003. P. 1.

2. Bartolo D., Blättler A., Deca L. Bologna at the Finish Line? Bologna at the Finish Line: An Account of the Ten Years of European Higher Education Reform. 2010. P. 16-17.

3. Baumann B., Bielecki A., Heerens N. Quality assurance - qualitative diversity? Bologna With Student Eyes. 2005. P. 23.

4. Cacciagrano A., Carapinha B., Gielis I. Executive Summary. Bologna With Student Eyes. 2009. P. 11-14.

5. Mikkola A., Carapinha B., Tück C. Quality Assurance. Bologna With Student Eyes. 2007. P. 15-16.

6. O’Driscoll C., Fröhlich M., Gehrke E. Quality Assurance. Bologna With Student Eyes. 2015. P. 37.

7. Päll A., Xhomaqi B., Bartolo D. Executive Summary Bologna With Student Eyes 2012. Bologna With Student Eyes. 2012. P. 8-9.

8. Sundberg C., Koppel K., Schwitters H. Quality Assurance. Bologna With Student Eyes. 2018. P. $52-53$.

\section{REFERENCES}

1. Almqvist J., Baumann B., Fontes P. Introduction to ESIB. Bologna With Student Eyes. 2003. P. 1.

2. Bartolo D., Blättler A., Deca L. Bologna at the Finish Line? Bologna at the Finish Line: An Account of the Ten Years of European Higher Education Reform. 2010. P. 16-17.

3. Baumann B., Bielecki A., Heerens N. Quality assurance - qualitative diversity? Bologna With Student Eyes. 2005. P. 23.

4. Cacciagrano A., Carapinha B., Gielis I. Executive Summary. Bologna With Student Eyes. 2009. P. 11-14.

5. Mikkola A., Carapinha B., Tück C. Quality Assurance. Bologna With Student Eyes. 2007.P. 15-16.

6. O’Driscoll C., Fröhlich M., Gehrke E. Quality Assurance. Bologna With Student Eyes. 2015. P. 37.

7. Päll A., Xhomaqi B., Bartolo D. Executive Summary Bologna With Student Eyes 2012. Bologna With Student Eyes. 2012. P. 8-9.

8. Sundberg C., Koppel K., Schwitters H. Quality Assurance. Bologna With Student Eyes. 2018. P. $52-53$. 